\title{
A Bibliometric Analysis of Study on Seaweed Industry for Strengthening Regional Competitiveness in Indonesia
}

\author{
Muhammad Gunawan Sani Saputro* \\ Management and Business, IPB University \\ PO box 16128, Jl. Raya Pajajaran, RT.03/RW.06, Bogor, Indonesia \\ Nunung Nuryartono \\ Management and Business, IPB University \\ PO box 16128, Jl. Raya Pajajaran, RT.03/RW.06, Bogor, Indonesia \\ Bustanul Arifin \\ Management and Business, IPB University \\ PO box 16128, Jl. Raya Pajajaran, RT.03/RW.06, Bogor, Indonesia \\ Nimmi Zulbainarni \\ Management and Business, IPB University \\ PO box 16128, J1. Raya Pajajaran, RT.03/RW.06, Bogor, Indonesia
}

\begin{abstract}
The Indonesian seaweed industry is currently experiencing a paradox that comparatively superior in the view of local production but inferior in the global market. Moreover, the strategic geographical location with the longest coastline the meeting of the world's largest coral triangle is not contributing to increase the local production. This work aims to develop the landscape of study on seaweed industry using bibliometric analysis. While historical of seaweed production in Indonesia is reflected to develop the required pre-condition in strengthening seaweed-based nation competitiveness. Research shows the biological study on this field that still in prevalent attention based on 500 article and less attention on the study on the upstream. The research on carrageenan as the raw material of seaweed have been developed widely. The actor of research and regulator in Indonesia needs to recognize more upstream strategy to strengthen the capacity of each actor in the supply chain.
\end{abstract}

Keywords: bibliometric, competitiveness, supply chain, seaweed, technology diffusion, upstream

DOI: $10.7176 / \mathrm{EJBM} / 13-6-06$

Publication date:March $31^{\text {st }} 2021$

\section{Introduction}

The capacity of agricultural, fishery and salt production in the coastal areas of Indonesia are still in suboptimal. Even though Indonesia is known as the country with the second longest coastline in the world. Derivative product on coconut and salt are two commodities which imported. Problem may vary from the problem of old mechanical equipment, conventional production process until the fail to fit with international standard.

The market opportunity for Indonesian seaweed exports is quite wide for cultivator producers, due to Indonesia's suitable geographical conditions and relatively stable seaweed prices. These three conditions are of course the potential for state revenue in the form of trade balance and foreign exchange. Seaweed is also a prime mover for the coastal economy where $60 \%$ of the Indonesian population lives within a $50 \mathrm{KM}$ radius of coastal and marine areas (Mertins et al., 2002). The population of coastal communities is defined as a group of people who live in coastal areas and their economic livelihoods depend directly on the utilization of marine and coastal resources. The number of fishermen in Indonesia is only around 2,164,969 people (Kementan RI, 2014). Indonesia has more than enough capital to make its seaweed industry superior at home and abroad. Indonesia is an archipelago country with the longest coastline, which is 99,000 kilometers (km) (Hoffman, 2017).

With the position of the Indonesian archipelago which is on the equator in several areas (such as the islands of Sumatra, Kalimantan, Sulawesi, Halmahera and marine areas in Indonesia have relatively warm sun temperatures and have an impact on the development of good seaweed. The relatively warm sea temperature affects the waves that are not too big (Garnaut, 2008; Handbook of Sustainable Development, n.d.; Kates, 2010). This is a favorable supporting factor for seaweed cultivators in Indonesia, because seaweed will grow rapidly. Indonesia is also an archipelago with the largest number of islands in the world, namely 17,504 islands. Indonesia has the second highest capture fisheries production in the world in marine waters (Arimoto, 2016; Organisation for Economic Co-operation and Development and Centre for Co-operation with Non-members, 2005). The distribution of fishing areas in Indonesia reaches an area of about 5.8 million $\mathrm{km} 2$ which is divided into 11 Fisheries Management Areas of the Republic of Indonesia. The world's seaweed industry currently has a variety of new products, one of the latest products is to become a powder from certain types of seaweed as the strongest 
coating material for aircraft. China is the largest importer of seaweed in the world, which receives an average of more than $50 \%$ per year from Indonesia.

The largest countries in the world that produce processed seaweed are China (59\%), South Korea (11\%), Japan (10\%), the Philippines (6\%) (Msuya, 2011; White \& Wilson, 2015). The world's most exploited seaweeds are brown algae (up to $75 \%$ ), red algae $(25 \%)$ and some green algae $(0.5 \%)$. China and South Korea are the largest seaweed producing countries that can consume up to $6,000,000$ tons of wet seaweed per year with a value of about 5 billion US \$. However, various problems have caused the seaweed industry in Indonesia to never be superior to similar industries in other countries (Simanjuntak et al., 2017). Meanwhile, Porter (1980) states that competitive advantage is the main factor that can strengthen or otherwise weaken the superiority of an industry in a country with other countries. The approach to increasing the competitive advantage itself is one of the sub-studies in strategic management which will involve other concepts and theories to be able to realize the competitive advantage itself (Baldwin, 1999; Campbell et al., 2011; Rechenthin, 2004). Therefore, in an effort to increase the competitive advantage of the Indonesian seaweed industry, focused and comprehensive research is needed. Such research must comprehensively address all viewpoints from various stakeholders. The research that is carried out must also be able to provide novelty contributions in the form of a synthesis of various strategic theories of increasing competitive advantage at the existing industrial level.

This is of course related to the competitive advantage of the Indonesian seaweed industry which is still low. The development of the seaweed processed commodity industry in Indonesia is still considered minimal, so the processed products have not developed properly. On the downstream side, the problem lies in the lack of innovative branding formulations for processed products (carrageenan) from seaweed raw materials. In addition, a number of problems and strategic challenges such as low technical mastery of cultivation, selling prices and limited access to the seaweed market and group institutional problems need to be addressed immediately. In general, the seaweed market structure in Indonesia is still considered inefficient (Hikmayani et al., 2015, 2017)

Lack of competitiveness in the aspect of innovation can also be seen in the absence of a road map for the development of the national seaweed industry. The road map should describe the vision and division of roles among stakeholders. In fact, in some previous research, government support as a stakeholder in innovation and industrial regulations that are production and distribution in nature can encourage industrial competitiveness (Hikmayani et al., 2015, 2017). Innovations can mitigate the impact that seaweed can have during the production and distribution process. Innovation can also increase the capacity and diversification of products derived from seaweed. The government has not really dared to control the export of raw seaweed, which reaches $90 \%$ in total to countries such as China, the Philippines, South Korea and several European Union countries. Stopping the export of raw materials if done will help increase the added value of the processed seaweed industry in the country, which is also supported by the current situation of( international buyers who have anticipated that Indonesia will stop exporting(Fateha et al., 2019; E. Wibowo et al., 2018).

There are two theories that are quite often associated with increasing competitive advantage at the level of traditional-modern industries such as the seaweed industry. The first theory is the diffusion theory of innovation which discusses the importance of spreading innovation in increasing industrial competitive advantage(Fadli et al., 2018; Luhur et al., 2017; Zaid, 2020). The second is the theory of Tripple Helix Plus which discusses the division of roles among stakeholders in order to accelerate the spread of innovation and increase the competitive advantage of the industry (Etzkowitz \& Leytesdorff, 1997; L Leydesdorff \& Etzkowitz, 2000; Loet Leydesdorff, 2017)

Based on the background and theoretical framework of Competitiveness Advantage, Diffusion of Innovation and Triple Helix Plus, it can be mapped the problems of the competitive advantage of the Indonesian seaweed industry related to innovation and collaboration between stakeholders. It is thought that innovation does not touch the root of the problem and business actors among cultivators as well as small entrepreneurs (Lovatelli, 2007; Robinson \& Lovatelli, 2015). Innovations are not well absorbed, so there is a gap between the real need for applicable innovation and research and support from all stakeholders. In the long run, these problems are thought to be a source of weak competitive advantage in the Indonesian seaweed industry. So the research problem that would answered by this research is how should the regulator (agent) develop strategy to increase the seaweed production capacity.

\section{Method}

This research took place in Indonesia. This study considers the sample population with the criteria of being players of the seaweed cultivation industry. This research was started in early September 2018 and finished at the end of June 2019. Meanwhile, the data collection process started from March to May 2019.

The bibliometric analysis is utilized in this research as main tool. Descriptive study has been conducted in strengthened the result of analysis.

Bibliometrics is the use of statistical methods to analyze books, articles and other publications. Bibliometric methods are frequently used in the field of library and information science. The sub-field of bibliometrics which concerns itself with the analysis of scientific publications is called scientometrics. 


\section{Result and Discussion}

\subsection{Study and Trade of Seaweed in the World}

China, Japan and Korea as the recipient countries of seaweed exports from Indonesia which consumed seaweed as food alone in 2005 reached 2 billion USD, which is inversely proportional to Indonesia at that time where seaweed was only allowed to float in the sea, being carried away. currents, washed ashore and left as marine debris(Arif, 2019; S. Wibowo \& Yunizal., 1998). Until now, seaweed in Indonesia is limited only as a food ingredient for residents living in coastal areas and not many industrial circles are interested in developing the potential of seaweed. Indonesia targets to be able to make seaweed as the country's leading commodity by producing 10 million tons of wet seaweed and 1 million tons of dry seaweed each year, the amount of production is very large but the absorption of seaweed in the country is still relatively small Meanwhile, the development of the seaweed industry has started to grow in the country, especially the agar and carrageenan industry.

The potential for seaweed production and development in Indonesia is actually quite large. In 2015 recorded the achievement of seaweed production as much as 10.2 million tons (wet seaweed) exceeding the production target in 2014 and beating the production of other commodities such as shrimp, grouper, snapper, milkfish, goldfish, tilapia, catfish and carp. This production achievement is supported by the Ministry of Marine Affairs and Fisheries through regular guidance to the community in the cultivation of seaweed. In terms of the processing and absorption industry, Indonesian seaweed feels a lack of raw materials because almost $64.31 \%$ of the dried seaweed is destined for export and only $35.69 \%$ of the dried seaweed is absorbed by industry players for agar and carrageenan. At least processed seaweed in their own country due to; (1) the export price is more favorable, especially to the People's Republic of China (PRC) and (2) the high cost of logistics is still high. This condition encourages the domestic price of (dry) seaweed to be expensive, where the seaweed policy in Indonesia is not yet fully comprehensive and operational so that the absorption of dried seaweed in the country is still relatively small.

Dried seaweed in Indonesia is mostly used for the jelly industry $(52.3 \%)$ and carrageenan $(47.7 \%)$, where the seaweed processing industry in Indonesia has begun to develop as an agar-food ingredient. In order to start in 1930 and in 1989 the carrageenan industry was developed. In1993 the alginate industry (made from Sargassum seaweed) was developed. Until 2018 the number of industries in Indonesia for agar there were 14 companies and the carrageenan industry was 16 companies. Table 1 shows that there are 3 (three) largest companies engaged in the jelly industry with a market share of 54.4\%, namely PT. Agarindo Bogatama, PT. Agar Swallow, and PT. Java Bio-Colloid.

Table 1 Jelly Industry Market-share

\begin{tabular}{|l|c|c|}
\hline \multicolumn{1}{|c|}{ Company } & Production Capacity/year & Marke share (\%) \\
\hline Industri Agar-agar & 5.4 & 100 \\
\hline PT. Agarindo Bogatama & 1.2 & 22,2 \\
\hline PT. Agar Swallow & 1.2 & 22,2 \\
\hline PT. Java Bio-Collaid & 540 & 10 \\
\hline PT. Surya IndoAlgas & 480 & 8,9 \\
\hline CV. Agar Sari Jaya & 480 & 3,9 \\
\hline PT. Srigunting & 200 & 1,9 \\
\hline PT. Indoflora Cipta Mandiri & 100 & n.a \\
\hline PT. Agar Sehat Makmur Lestari & n.a & n.a \\
\hline PT. Gracindo Nusantara & n.a & n.a \\
\hline PT. Indoking Aneka Agar-agar & n.a & n.a \\
\hline CV. Sinar Kentjana & n.a & n.a \\
\hline PT. Satelit Sriti & n.a & n.a \\
\hline PT. The Nine & n.a & n.a \\
\hline PT. Pantai Samudra & n.a & \\
\hline
\end{tabular}

Source: (Ministry of Maritime and Investment Republic of Indonesia, 2018)

The carrageenan industry in Indonesia reaches a market share of 56.4\%, however, Indonesia currently imports SRC (Semi Refined Carrageenan) raw materials from China (China) due to technological factors through research and development of domestic production which are still relatively limited and the price of raw materials is more expensive. Another reason for Indonesia to import, from China and also Europe, is the limited number of seaweed derivative products in Indonesia when compared to other countries. This condition causes the price and quality of Indonesian seaweed industry products to be less competitive with industrial products from China. Table 2 shows the four major carrageenan industry companies, namely PT. Indonusa Algaemas Prima, PT. Galic Artha Bahari, PT. Indo Seaweed and PT. Gumindo Perkasa Industri. 
Table 2 Market share of Carrageenan 2014

\begin{tabular}{|l|c|c|}
\hline \multicolumn{1}{|c|}{ Carrageenan Industry } & Production 2013 (MT) & Market Share (\%) \\
\hline Industri Karaginan & 12.5 & 100 \\
\hline PT. Indonusa Algaemas Prima & 2 & 16,1 \\
\hline PT. Galie Artha Bahari & 2 & 16,1 \\
\hline PT. Indo Seaweed & 1.8 & 14,5 \\
\hline PT. Gumindo Perkasa Industri & 1.2 & 9,7 \\
\hline PT. Algalindo Perdana & 1 & 8 \\
\hline PT. Cahaya Cemerlang & 1 & 8 \\
\hline PT. Wahyu Putra Bimasakti & 1 & 8 \\
\hline PT. Amarta Carrageenan Indonesia & 1 & 5,8 \\
\hline PT. Hydrocolloid Indonesia & 7,2 & 5,2 \\
\hline PT. Centram & 650 & 0,5 \\
\hline PT. Kappa Carrageenan Nusantara & 60 & 0,6 \\
\hline PT. Giwang Citra Laut & 70 & n.a \\
\hline PT. Algae Sumba Timur & n.a & n.a \\
\hline PT. Batimurung Indah & n.a & n.a \\
\hline PT. Karaginan Indo Mandiri & n.a & n.a \\
\hline PT. Phoenix Mas & n.a & \\
\hline Sur & . & \\
\hline
\end{tabular}

Sumber (Ministry of Marine Affairs and Fisheries Republic of Indonesia, 2014)

Another problem for seaweed business actors in Indonesia is pricing. The price of seaweed varies at the farmer and collector level according to the production center area and the marketing pattern of seaweed from farmers to consumers (exporters and processing factories) which is carried out through one or two levels of marketing patterns. This difference in marketing patterns distinguishes the margins and the share of prices received by seaweed farmers. So far, the price received by farmers is still low due to lag in price information and industry absorption between farmers and the market and the weak commitment between farmers and buyers, which affects the export market. Other things that also affect the price of seaweed are the type and season of harvest and the quality of cleanliness and the level of dryness of the seaweed. Considering the demand for seaweed to meet the processing and export industries, price is an important indicator that needs to be considered for seaweed industry entrepreneurs in Indonesia.

Farmers borrow funds from the local-informal-bankers before planting seaweed, then start the production process which consists of planting seaweed and harvesting it and producing seaweed (after drying) with a harvest time of between 45-60 days (depending on the region and season). Freshly harvested seaweed should not be placed in a dark place but must be dried directly in the sun because it will affect the final color of the seaweed. The best time to dry the freshly harvested seaweed is between $6.30 \mathrm{am}$ and $5 \mathrm{pm}$. After getting the dried seaweed, the farmers will return the money to the middlemen and also sell their crops to the middlemen. Middlemen play an important role, especially in providing the funds needed by farmers quickly and collecting and buying dried seaweed from farmers (Zamroni et al., 2017; Zamroni \& Yamao, 2011)

The production of dried seaweed by farmers in Indonesia depends on middlemen from the start to the end, causing farmers to be less informed about prices and productivity, which are classified as low. The distortion in the sales price of Indonesian seaweed can occur if the export demand (by the PRC) increases many times as usual, where the demand by the PRC is outside the general price, causing the price of seaweed to decline in the following months so that farmers need to harvest the seaweed before harvest time. The Ministry of Trade implemented the Warehouse Receipt System (SRG) program in 2013 for seaweed industry players after the production process is complete until the harvest stage. This is done to anticipate price distortions as described. However, the warehouse receipt program was not implemented well in the case in South Sulawesi where utilization was only 420 tons, while exports from South Sulawesi in October 2014 reached 95,462 tons (CNN Indonesia, 2014).

Seaweed cultivation has competitiveness in the price level and technology used and is interconnected with industry players, namely farmers, local traders, processors, exporters and so on. Competitiveness which is the analysis in this study is at the company, industry, to national or state levels. At this level, competitiveness is measured through the productivity and distribution of capital owned. The development of the innovation diffusion study in this research is to maintain and develop the competitive advantage in an organization. The support and collaboration of stakeholders in this seaweed industry research is also an important concern.

The 200 samples taken from Elsevier's official website using the keyword "Seaweed" then processed using the VOSviewer software can be seen in Figure 1, that during the last 10 years the development of research on seaweed in the world still focuses on biological aspects. There are very few studies that discuss food analysis and other business functions. Thus, seaweed research in an industrial context is a research that is expected to encourage and develop the boundaries of studies on "seaweed". 


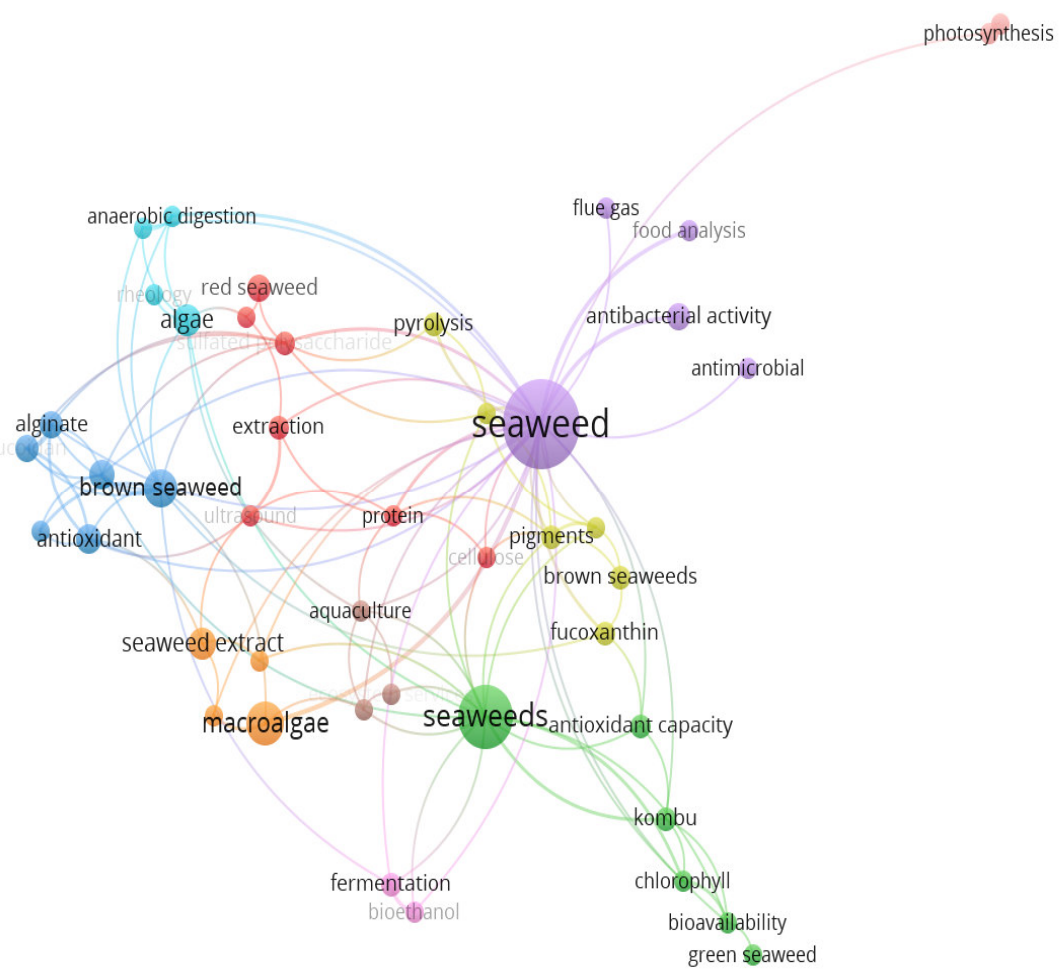

Figure 1 "seaweed" as a keyword in VOSviewer

The same thing was also found in 142 samples taken from Elsevier's official website using the keyword "Seaweed Industry" then processed using VOSviewer software, it can be seen in Figure 2, that during the last 10 years the development of research on the seaweed industry in the world is still focused on aspects biology. There are hardly any studies that discuss the advantages of industrial competitiveness associated with the diffusion of innovation and the triple helix theory of seaweed. Thus, research on the seaweed industry in the context of industrial competitiveness excellence is a research that is expected to push and develop the boundaries of studies on the "seaweed industry".

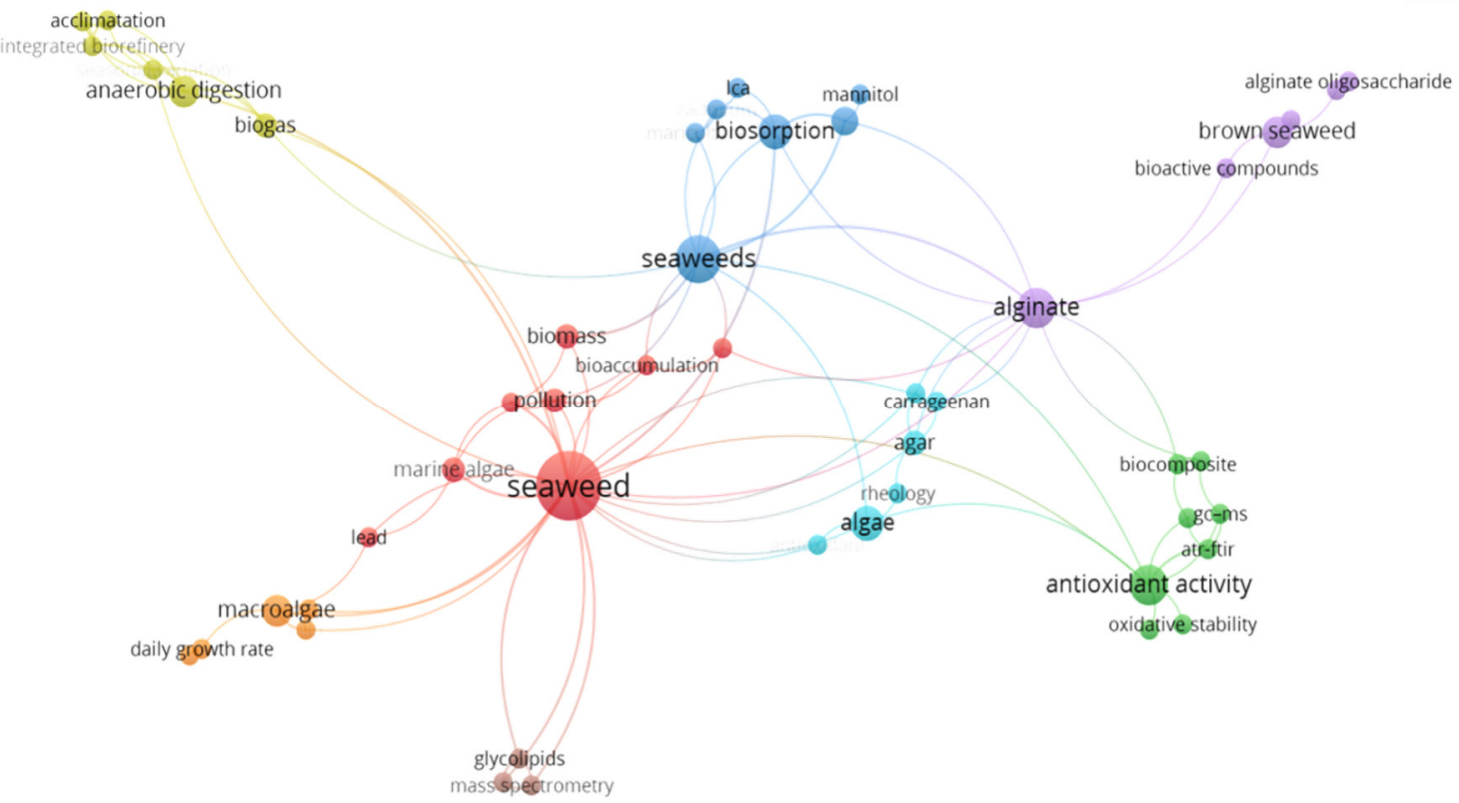

Figure 2: "seaweed industry" as a keyword in VOSviewer

In 500 research publications with the keywords innovation and innovation diffusion taken from Elsivier's official website then processed using the VOSviewer software (van Ech, N.L \& Waltman, 2014; N. J. van Eck \& Waltman, 2009, 2010, 2014; N. Van Eck \& Waltman, 2010; Waltman \& van Eck, 2009; Waltmand \& van Eck, 2015), it can be seen in Figures 2 and 3, that during the last 10 years the development of research on innovation in the world still focuses on aspects of the attributes of innovation, performance. innovation, the open nature of 
innovation, and sustainability. Almost no research is found that discusses the diffusion of innovation in which there are complex attributes including attributes of innovation, change agents, communication media and social culture. Thus, research on the seaweed industry in the context of diffusion of innovation is a research that is expected to push and develop the boundaries of studies regarding the "seaweed industry" and "innovation" itself.

\subsection{Existing role of government on the sea}

Data from the Ministry of Industry from 2014 to 2015 recorded that the total production of processed seaweed products reached 15,638 tons per year from a total of 18 business units, including five (5) agar industry business units, two (2) Refine Carrageenan industrial business units (RC) and 11 Semi Refined Carrageenan (SRC) industrial business units.

Law Number 9 of 2006 concerning the Warehouse Receipt System (SRG) from the government aims to maintain price stability and protect seaweed farmers. Then the law regarding the Warehouse Receipt System has a derivative regarding the Republic of Indonesia's Government Regulation Number 36 of 2007 concerning Implementation of Law Number 9 of 2006 concerning the Warehouse Receipt System and the Minister of Trade Regulation Number 26 / M-DAG / PER / 6/2007 concerning Goods That Can Be Stored in the Warehouse (Grain, Rice, Coffee, Cocoa, Pepper, Rubber, Seaweed and Corn), Regulation of the Minister of Trade of the Republic of Indonesia Number 66 / M-DAG / PER / 12/2009 concerning Implementation of Warehouse Receipt Subsidy Schemes, as well as various Regulations of the Head of Commodity Futures Trading Supervisory Agency of the Ministry of Trade (Bappebti ${ }^{1}$ ) as operational guidelines. The four important regulations in the SRG Policy are Law no. 9 of 2006 concerning the SRG which later underwent several changes through Law no. 9 of 2011, Government Regulation no. 36 of 2007 concerning the Implementation of the SRG, Regulation of the Minister of Finance No. 171 of 2009 concerning the Warehouse Receipt Subsidy Scheme and Regulation of the Minister of Trade No. 26 / M-DAG / PER / 6/2007 concerning Items that can be stored in warehouses during the SRG arrangement which is then changed by including seaweed as one of the goods that can be reared through the Minister of Trade Regulation No.26 / M-DAG / PER / 6 / 2007 regarding goods that can be stored in warehouses during the SRG.

However, in reality, the policy regarding warehouse receipts has not been implemented in all seaweed production centers. South Sulawesi is an example of a production center that applies a warehouse receipt system (SRG). The cause of not implementing the Warehouse Receipt System for seaweed commodities properly is the fact that technical, economic and regulatory aspects are not effective in terms of the use of financing facilities, namely the not yet integrated existing credit schemes such as People's Business Credit (KUR) and Food and Energy Financing Loans (KPPE). The Ministry of Marine Affairs and Fisheries (KKP) continues to strive to increase the production of seaweed commodities in 2010 by implementing policies through the concept of a mina ${ }^{2}$ politan area. Regulation of the Minister of Marine Affairs and Fisheries of the Republic of Indonesia No. 12 of 2010 Regulation of the Minister of Marine Affairs and Fisheries of the Republic of Indonesia No. 12 of 2010 regarding development area-based economy and fisheries based on the principles of integration, efficiency, quality and acceleration with the main economic function of production centers, processing, marketing of fishery commodities, services and other supporting activities. The concept of a minapolitan area divides into three zoning zones as production zones, economic institutions and buffer zones as well as industrial processing zones, as follows

1. Production Zone (zone for producing grass until ready to harvest)

2. Economic Institutional Zone and Buffer (zone of cooperation between production facilities zone with the purchase of seaweed production to control and guide the methods of seaweed cultivators.

3. Processing industry zone (a special zone for purchasing seaweed from zone two in accordance with agreed standards and has the task of processing the seaweed that has been harvested.

The policy effort for the Minapolitan area concept has been well implemented in Indonesia in the development of seaweed commodity in East Sumba Regency, East Nusa Tenggara Province. From 2010 to 2014 the area has significantly increased the production of seaweed from a yield of 439.9 tons in 2010 then increased to 1,560.4 tons in 2014. The total yield obtained in 2014 was 2,400 tons. East Sumba Regency follows the entire business system from upstream to downstream including production, processing and marketing in the Minapolitan area supported by adequate infrastructure for transportation and production facilities. This is the reason why East Sumba Regency won the "A" category for the Minapolitan area (KKP, 2015).

The government and the KKP are also making efforts to increase the added value of national seaweed production with the Foreign Buyer Mission program, which is an activity carried out on 27-30 May 2014 in collaboration with The Swiss Import Promotion Programmer (SIPPO) with the aim of facilitating Indonesian exporters to meet importers and provide opportunities for foreign investors to invest, transfer knowledge and technology, processing and market trends for non-raw (semi-refined) products that have added value such as agar-

\footnotetext{
${ }^{1}$ Acronym of Badan Pengawas Perdagangan Berjangka Komoditi Kementerian Perdagangan

${ }^{2}$ The city with integrated concept of marine and fishery ecosystem.
} 
agar and carrageenan (SWA, 2014). In 2015, the government had a new policy discourse on targets for 2018 to 2020 to impose export duties (BK) on seaweed for E. cottony (25\%), Gracillariid (44 \$) and Spinosum (12\%) with the aim of encouraging the domestic processing industry is able to compete with competitors from other countries. This government policy discourse received rejection from ARLI which stated that the absorption of raw seaweed by the processing industry was only $50 \%$ percent of the harvest in 2015 . In addition, the government, through President Joko Widodo in April 2015, has discouraged seaweed exports. raw in 2018. In fact, seaweed farmers can only rely on their seaweed harvest to sell, both for export and absorbed by foreign markets.

This is not supported by the competitiveness of domestic industries that cannot yet compete. The widespread impact if this government policy is still implemented from 2018 to 2020 is the transfer of the fulfillment of seaweed commodities from Indonesia to other countries such as the Philippines, Malaysia, Vietnam, Myanmar, Papua New Guinea, India and Brazil. The government has made the Indonesian National Standard (SNI) for products for agar flour, dried seaweed, agar paper, semi-refined carrageenan, seaweed dodol ${ }^{1}$, determination of carrageenan yield and the Indonesian National Standard Draft (RSNI) for products. Alkali Treated Seaweed Chips (ATSC), revision of dry seaweed, revision of starch agar, determination of impurities in seaweed, determination of moisture content and determination of Clean Anhydrous Weed (CAW) in seaweed. The National Standard applied by the government is useful for improving the quality and quality of Indonesian seaweed so that it is increasingly attractive to the international market.

In the framework of accelerating community economic development through the marine and fisheries sector, trade sector, industrial sector, cooperative sector and small and medium enterprises and investment in the marketing aspects of seaweed in seven underdeveloped provinces in Indonesia (South Sulawesi, Southeast Sulawesi, Central Sulawesi, Maluku, North Maluku, West Nusa Tenggara and East Nusa Tenggara) government through five ministries (State Ministry for Disadvantaged Regions, Ministry of Maritime Affairs and Fisheries, Ministry of Trade, Ministry of Industry and Ministry of Cooperatives and SMEs as well as the Investment Coordinating Board issued a Joint Agreement Letter (SKB) No 262 / M-DAG / MOU / 2/2011 concerning "the synergy of seaweed development activities in the context of accelerating the economic development of disadvantaged areas in seven provinces." The Joint Agreement was not only intended to develop the economy in disadvantaged areas but also to provide protection to farmers in cope with fluctuations in the commodity price of seaweed. Other policy plans so that the Indonesian seaweed industry is more synergized and focused, the government and the association have formed a roadmap including:

1. Tax Holiday for new industries

2. Allowance for existing industries

3. Application of Export Duty (Bea Keluar) for raw seaweed

4. Provision of soft credit for industry

5. Provision of quality Human Resources (HR)

6. Coordination with related agencies to increase the supply of quality raw materials as well as coordination with related agencies regarding infrastructure development in seaweed producing areas.

This intervention has been applied in both upstream and downstream of the supply chain of seaweed. However, the result is still far from the expectation (Maludin et al., 2019).

\section{Conclusion}

Contribution of seaweed industry to national GDP is still low. On the other side, based on the bibliometric analysis, shows that the studies on industrial competitiveness based on seaweed have been low. Thus, research on the seaweed industry in the context of industrial competitiveness excellence is expected to have more attention from both academic and industrial actors.

Government as un-natural party in the intervention in the collaboration between farmers in downstream actor and business unit in upstream, need to equipped with comprehensive role. It is required to save the stable capacity with transparent information about price and quality of seaweed

\section{References}

Arif, Y. Y. (2019). Back to Basics in the Importance of Market Orientation and Corporate Strategy to Bank Performances in Indonesia. American Journal of Economics and Business Administration, 11(1), 78-85. https://doi.org/10.3844/ajebasp.2019.78.85

Arimoto, T. (2016). Science Advice and Foresight under the Complex and Uncertain World. INGSA Website.

Baldwin, W. L. (1999). Industrial Policy and Competitive Advantage (Book Review). Small Business Economics, 13(4), 339.

Campbell, D., Edgar, D., Stonehouse, G., Campbell, D., Edgar, D., \& Stonehouse, G. (2011). Competitive advantage and strategy. In Business Strategy (pp. 192-209). https://doi.org/10.1007/978-0-230-34439-6_13

\footnotetext{
${ }^{1}$ Traditional food in made of brown sugar and flour in form of paste
} 
Etzkowitz, H., \& Leytesdorff, L. (1997). Universities in the Global Economy: A Triple Helix of academicindustry-government relation. London: Croom Helm.

Fadli, F., Pambudy, R., \& Harianto, H. (2018). Analisis Daya Saing Agribisnis Rumput Laut di Kabupaten Lombok Timur. Jurnal Agribisnis Indonesia, 5(2), 111. https://doi.org/10.29244/jai.2017.5.2.111-124

Fateha, Wibowo, S., Santoso, J., Agusman, \& Uju. (2019). Optimization of processing conditions of alkali treated cottonii (ATC) from sap-free eucheuma cottonii. Squalen Bulletin of Marine and Fisheries Postharvest and Biotechnology, 14(2), 65-72. https://doi.org/10.15578/squalen.v14i2.397

Garnaut, R. (2008). The Garnaut Climate Change Review (Cambridge University Press (Ed.)).

Handbook of Sustainable Development. (n.d.).

Hikmayani, Y., Aprilliani, T., \& Zamroni, A. (2017). Analisis Pemasaran Rumput Laut di Wilayah Potensial di Indonesia. Jurnal Sosial Ekonomi Kelautan Dan Perikanan, 2(2), 159. https://doi.org/10.15578/jsekp.v2i2.5869

Hikmayani, Y., Deswati, R. H., \& Nasution, Z. (2015). Evaluasi dan Strategi Peningkatan Keberhasilan Pelaksanaan Program Pengembangan Usaha Mina Pedesaan Perikanan Budidaya: Pendekatan Analisis Prospektif. Jurnal Kebijakan Sosial Ekonomi Kelautan Dan Perikanan, 3(1), 47. https://doi.org/10.15578/jksekp.v3i1.232

Hoffman, J. (2017). Maritime Connectivity: The Evolving Role of Ports in Global Shipping Networks.

Kates, R. W. (2010). Working Papers. 213.

Kementan RI. (2014). Renstra Kementrian Pertanian Pertanian Tahun 2015 - 2019. Hari Aids Sedunia $2014,2014$. https://doi.org/351.077 Ind r

Leydesdorff, L. (2017). Triple Helix of University-Industry-Government Relations. In Encyclopedia of Creativity, Invention, Innovation and Entrepreneurship (pp. 1-9). https://doi.org/10.1007/978-1-4614-6616-1_452-2

Leydesdorff, L., \& Etzkowitz, H. (2000). "Mode 2" and the Globalization of "National" Systems of Innovation: The Model of a Triple Helix of University-Industry-Government Relations. Sociologie et Societes, 32(1), $135-156$.

Lovatelli, A. (2007). Development of international guidelines on the use of wild fish for aquaculture production. FAO Aquaculture Newsletter, 37, 16-17.

Luhur, E. S., Witomo, C. M., \& Firdaus, M. (2017). Analisa Daya Saing Rumput Laut di Indonesia (Studi Kasus : Kabupaten Konawe Selatan, Sulawesi Tenggara). Jurnal Sosial Ekonomi Kelautan Dan Perikanan, 7(1), 55. https://doi.org/10.15578/jsekp.v7i1.5735

Maludin, S., Syarief, R., Rifin, A., \& Rochman, N. T. (2019). Strategic Choice of Technology Transfer in Indonesia, 5(1), 163-175.

Mertins, K., Albrecht, R., \& Carlo, L. De. (2002). Evaluation of the Indonesian Science, Research and Technology Landscape to Strengthen the National Innovation System Work Package 1: Assessment of Industry Needs. System.

Ministry of Marine Affairs and Fisheries Republic of Indonesia. (2014). Peraturan Menteri Kelautan dan Perikanan Republik Indonesia No.18/PERMEN-KP/2014 Tentang Wilayah Pengelolaan Perikanan Negara Republi Indonesia. In Peraturan Menteri (Vol. 2009).

Ministry of Maritime and Investment Republic of Indonesia. (2018). Maritime Coordinating Minister Launches Indonesian Marine Area Reference Data. Ministry of Maritime and Investment Republic of Indonesia.

Msuya, F. E. (2011). The impact of seaweed farming on the socioeconomic status of coastal communities in Zanzibar, Tanzania. World Aquaculture, 42(3), 45-48.

Organisation for Economic Co-operation and Development and Centre for Co-operation with Non-members. (2005). OECD Review of Agricultural Policies: China. In Review Literature And Arts Of The Americas. https://doi.org/10.1787/9789264012554-en

Porter, M. E. (1980). The Competitive advantage of Nation (1990). In Techniques for Analyzing Industries and Competitors : with a New Introduction.

Rechenthin, D. (2004). Project safety as a sustainable competitive advantage. Journal of Safety Research, 35(3), 297-308. https://doi.org/10.1016/j.jsr.2004.03.012

Robinson, G., \& Lovatelli, A. (2015). FAO Aquaculture Newsletter 53 - March 2015. FAO Aquaculture Newsletter, 53(May), 55-57.

Simanjuntak, P. T. H., Arifin, Z., \& Mawardi, M. K. (2017). Rupiah Terhadap Volume Ekspor Rumput Laut Indonesia. Journal of Business Administration, 50(3), 163-171.

van Ech, N.L \& Waltman, L. (2014). Visualizing bibliometric networks, in: Y. Ding, R. Rousseau, D. Wolfram (Eds.), Measuring Scholarly Impact: Methods and Practice. In Springer International Publishing, Cham.

van Eck, N. J., \& Waltman, L. (2009). VOSviewer: A Computer Program for Bibliometric Mapping - ERIM REPORT SERIES RESEARCH IN MANAGEMENT. Erim Report Series Research in Management, 886897.

van Eck, N. J., \& Waltman, L. (2010). Software survey: VOSviewer, a computer program for bibliometric mapping. 
Scientometrics, 84(2), 523-538. https://doi.org/10.1007/s11192-009-0146-3

van Eck, N. J., \& Waltman, L. (2014). Visualizing Bibliometric Networks. In Measuring Scholarly Impact (pp. 285-320). https://doi.org/10.1007/978-3-319-10377-8_13

Van Eck, N., \& Waltman, L. (2010). A Comparison of TwoTechniques for Bibliometric Mapping: Journal of the American Society for Information Science and Technology, 64(12), 2405-2416.

Waltman, L., \& van Eck, N. (2009). A simple alternative to the h-index. ERIM Report Series Research in Management Erasmus Research Institute of Management.

Waltmand, L., \& van Eck, N. J. (2015). Bibliometric network analysis: Software tools, techniques, and an analysis of network science at Leiden University [Powerpoint Presentation]. In LCN2.

White, W. L., \& Wilson, P. (2015). World seaweed utilization. In Seaweed Sustainability: Food and Non-Food Applications (pp. 7-25). https://doi.org/10.1016/B978-0-12-418697-2.00002-7

Wibowo, E., Ario, R., Suryono, S., Taufiq, N., \& Destalino, D. (2018). Struktur Komunitas Rumput Laut di Perairan Pasir Panjang Desa OlibuuKabupaten Boalemo, Gorontalo. BULETIN OSEANOGRAFI MARINA, 7(1), 59. https://doi.org/10.14710/buloma.v7i1.19081

Wibowo, S., \& Yunizal. (1998). Penanganan ikan segar. Instalasi Perikanan Laut Slipi. Jakarta., 1(1).

Zaid, S. (2020). The product innovation of seaweed moringa chips: An antecedent to customer value and competitive advantage. International Journal of Innovation, Creativity and Change, 12(10), 275-285.

Zamroni, A., Amano, M., \& Yamao, M. (2017). A Brief Comparison of Fisheries Livelihoods Strategy: Countries Experiences of Japan and Indonesia. International Journal of Marine Science. https://doi.org/10.5376/ijms.2017.07.0038

Zamroni, A., \& Yamao, M. (2011). Sustainable Household Economics: A Case of Altering Income of Small-Scale Fishermen in Indonesia. 2011 International Conference on Financial Management and Economics, 11, 343347. 